\title{
FIRE TESTS ON WOOD PRODUCTS SUBJECTED TO DIFFERENT HEAT FLUXES
}

\author{
Romualdas Mačiulaitis ${ }^{1}$, Vladas Praniauskas ${ }^{2}$ \\ Department of Building Materials, Vilnius Gediminas Technical University, Saulètekio al. 11, \\ LT-10223 Vilnius, Lithuania \\ E-mail: ${ }^{1}$ romualdas.maciulaitis@vgtu.lt; ${ }^{2}$ vladas.praniauskas@vgtu.lt \\ Received 14 Oct. 2009; accepted 01 Jun. 2010
}

\begin{abstract}
The paper analyses three different wood products used for research exposing them to the surface heat flow density of $30 \mathrm{~kW} / \mathrm{m}^{2}, 50 \mathrm{~kW} / \mathrm{m}^{2}$ and $70 \mathrm{~kW} / \mathrm{m}^{2}$ and applying the test method described in ISO 5660-1 Reaction-to-fire tests Heat release, smoke production and mass loss rate - Part 1: Heat release rate (Cone calorimeter method). Research was performed applying $18 \mathrm{~mm}$ and $29 \mathrm{~mm}$ thick laminated wood chipboards and $24 \mathrm{~mm}$ thick medium density fibreboard. The paper provides an overview of the fire properties of wood products and discusses testing methods and the percentage composition of the tested wood products. Mean time to their ignition was determined. The mean values of the maximum heat release rate and time required to achieve them were investigated. Furthermore, the measurements of the released heat and efficient heat of combustion were taken. Further research covers the performance of statistic analysis, deriving empiric equations, correlation and determination coefficients, standard errors and Student criterion. The results of research are summarized. Conclusions are provided at the end of the paper.
\end{abstract}

Keywords: time to ignition, time to the maximum heat release rate, maximal heat release rate, total heat released, wood products, fire properties.

\section{Introduction}

Fire safety is one of the essential requirements for objects. It is important that any indoor finishing elements made of wood, in case of fire, posed as little hazard as possible to inhabitants and rescue workers. This objective can be implemented using only the products that have properties restricting fire spread rate. In terms of product fire safety, it is of topmost importance that the tests by exposing products to heat flows were carried out in a complex manner, taking into account the heat release rate, the decomposition of products (pyrolysis), the toxicity of materials emitted during combustion, and the amount of resulting smoke (White 2000; Nyderis and Mačiulaitis 1999; Konecki and Półka 2009 ).

The heat release rate, which is considered an important fire property, is of great significance to fire spread. This statement is substantiated by the fact that fire temperature conditioning the fire spread rate first of all depends on the heat release rate and combustion time (WładykaPrzybylak 1997).

Most fire properties were investigated based on oxygen consumption and calorimetric measurements. Fire criteria are empiric values that also depend on other criteria (Jaskółowski 2001).

In Harada (2001) published collected literaturebased data (time to ignition, the heat release rate and the reaction-to-fire of nine different wood species having different density and thickness). This wood was studied by exposing it to the surface heat flow of different density. During the carried out tests, he determined that the reaction-to-fire of wood depended on its species, sample dimensions and heating conditions (Harada 2001). The most effective factor affecting the reaction-to-fire properties of wood is its density. This is related to thermal conduction and thermal capacity. It has been proved that along with an increase in density, the ignition time of wood and the heat release rate get higher (Drysdale 1998; Mačiulaitis and Lukošius 2001).

One of a few obvious researches on fire properties in wood products are those by Gardner and Thomson. The research results of these authors proved that the ignition time of wood products increased as product density got higher. The maximal heat release rate and total released heat increased with an increase in heat flow. Research was carried out in a Room Fire Facility using the method of Room Fire Tests of Wall and Ceiling Lining Materials and Assemblies (Gardner and Thomson 1991).

The test results published by Parker and Tran are also of interest. The former proposed a thermo-kinetic combustion model using the thermo-kinetic properties of wood. The latter in a complex manner investigated the thermo-kinetic and thermo-physical properties of eight species of wood by exposing them to the surface heat flow of three density values: 28,40 and $50 \mathrm{~kW} / \mathrm{m}^{2}$. The obtained correlative dependences evaluated the influence of wood sample orientation depending on the capacity of heating element, wood density, external heat flow density affecting wood being tested and release rate of wood combustion heat (Parker 1982; Tran 1988).

In 1990-1991, National Fire Laboratory, Institute for Research in Construction and researcher Andrew Kim 
from the National Research Council of Canada, Ottawa carried out tests on thirteen typical building materials of different thickness (plywood, wood chipboard, expanded polyurethane, polystyrene, etc.) and determined time to ignition (TTI), maximal heat release rate $\left(\mathrm{HRR}_{\max }\right)$, total heat released (THR), peak heat released (PHR) and time to peak heat release $\left(t_{\mathrm{PHR}}\right)(\mathrm{Kim} 1994)$.

The aim of our work is to determine the most important criteria conditioning the reaction-to-fire of wood products.

\section{Materials tested and testing methods}

Research was conducted applying widely used finishing materials such as medium density fibreboards and two laminated wood chipboards of different thickness.

Laminated wood chipboards (LWCB) are made by hot pressing of wood chips after binding and stiffening agents are added. The resulting boards are glued with the laminate of the chemical composition presented in Table 1 . The percentage composition of 18 and $29 \mathrm{~mm}$ thick LWCB boards include wood (in the form of chips) $\sim 84 \%$, water $\sim 6 \%$ and chemical substances $\sim 10 \%$. The chemical composition of this board is presented in Table 2. The average density of these boards was $707 \mathrm{~kg} / \mathrm{m}^{3}$.

Medium density fibreboards (MDF) are made by pressing wood fibre after organic binding and stiffening agents are added exposing them to high temperature and high pressure. The percentage composition of $24 \mathrm{~mm}$ thick MDF board makes wood (in the form of fibre) $\sim 84 \%$, water $\sim 4 \%$ and chemical substances $\sim 12 \%$. The chemical composition of this board is presented in Table 2 . The average density of these boards was $709 \mathrm{~kg} / \mathrm{m}^{3}$. As the average densities of the boards chosen for testing purposes are much the same, it is not necessary to consider their density when analysing and comparing fire criteria of wood products.

For the purposes of fire hazard research on wood products, a cone calorimeter was used, the measurements of which are based on oxygen consumption and calorimetry (in accordance with ISO 5660-1 2002 standard).

Table 1. The average amount of chemical substances per $1 \mathrm{~m}^{3}$ of laminate

\begin{tabular}{l|c|c}
\hline & $\begin{array}{c}\text { LWCB } \\
(18 \mathrm{~mm})\end{array}$ & $\begin{array}{c}\text { LWCB } \\
(29 \mathrm{~mm})\end{array}$ \\
\hline $\begin{array}{l}\text { Carbamide-Melamine- Formaldehyde } \\
\text { Adhesive }\end{array}$ & $12.8 \mathrm{~kg} / \mathrm{m}^{3}$ & $12.8 \mathrm{~kg} / \mathrm{m}^{3}$ \\
\hline
\end{tabular}

Table 2. The average content of chemical substances per $1 \mathrm{~m}^{3}$ of board

\begin{tabular}{l|c|c|c}
\hline & $\begin{array}{c}\text { MDF } \\
(24 \mathrm{~mm})\end{array}$ & $\begin{array}{c}\text { LWCB } \\
(18 \mathrm{~mm})\end{array}$ & $\begin{array}{c}\text { LWCB } \\
(29 \mathrm{~mm})\end{array}$ \\
\hline $\begin{array}{l}\text { Carbamide- } \\
\text { Formaldehyde Adhesive }\end{array}$ & $79 \mathrm{~kg} / \mathrm{m}^{3}$ & $65 \mathrm{~kg} / \mathrm{m}^{3}$ & $65 \mathrm{~kg} / \mathrm{m}^{3}$ \\
\hline Paraffin & $5.64 \mathrm{~kg} / \mathrm{m}^{3}$ & $2 \mathrm{~kg} / \mathrm{m}^{3}$ & $2 \mathrm{~kg} / \mathrm{m}^{3}$ \\
\hline $\begin{array}{l}\text { Stiffening Substance } \\
\text { (Ammonium Sulphate) }\end{array}$ & $1.5 \mathrm{~kg} / \mathrm{m}^{3}$ & $\begin{array}{c}1.2 \mathrm{~kg} / \\
\mathrm{m}^{3}\end{array}$ & $\begin{array}{c}1.2 \mathrm{~kg} / \\
\mathrm{m}^{3}\end{array}$ \\
\hline
\end{tabular}

This test method is based on the fact that the total combustion heat is essentially proportional to the amount of oxygen required for combustion. The ratio is such that when $1 \mathrm{~kg}$ of oxygen is used, $13.1 \times 10^{3} \mathrm{~kJ}$ of heat is emitted. The main elements of the device are as follows: conical heater, scales, ignition source, exhaust hood, protective wall, oxygen analyser and a dynamic measurement system for smoke generation (Fig. 1).

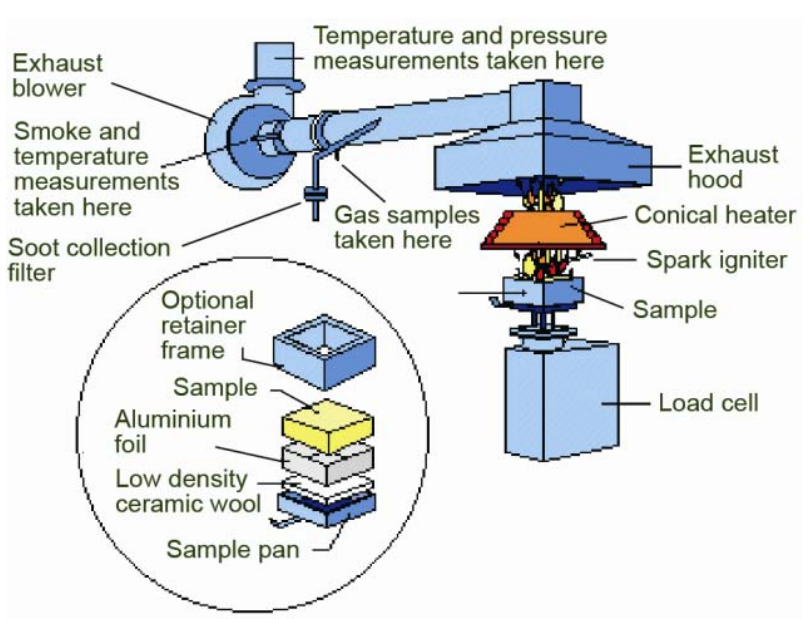

Fig. 1. The general view of a cone calorimeter

The samples of real board thickness were cut out from the boards tested $(100 \mathrm{~mm} \times 100 \mathrm{~mm})$, wrapped in aluminium foil (except the top part exposed to heat flow), placed on the holder and fixed to the frames.

Then, the foil-free side of every sample was exposed to the surface heat flow density of $30 \mathrm{~kW} / \mathrm{m}^{2}$, $50 \mathrm{~W} / \mathrm{m}^{2}$ and $70 \mathrm{~kW} / \mathrm{m}^{2}$.

As all samples were tested in the horizontal position and for every sample, the following was set: time to ignition (TTI $[\mathrm{s}])$, maximal heat release rate $\left(\mathrm{HRR}_{\max }\right.$ $\left.\left[\mathrm{kW} / \mathrm{m}^{2}\right]\right)$, time to maximal heat release rate $\left(\mathrm{T}_{\text {HRRmax }}[\mathrm{s}]\right)$, total heat released (THR $\left.\left[\mathrm{MJ} / \mathrm{m}^{2}\right]\right)$ and efficient heat of combustion (EHC $[\mathrm{MJ} / \mathrm{kg}]$ ).

Ten samples of each type of the board were tested.

Statistical analysis was performed using the method of the least square based on the principle of the gradual entering of criteria used for calculating correlation $(\mathrm{R})$ and determination $\left(\mathrm{R}^{2}\right)$ coefficients and standard errors $\left(\mathrm{S}_{\mathrm{e}}\right)$. On the basis of Student criteria and making comparison with the ones in the table, the arguments exceeding them were selected (Боровиков 1998; Kleinbaum et al. 1998).

\section{Research results and discussion}

Fig. 2 shows time to ignition, i.e. the occurrence of stable flame on the sample surface. In this case, it was determined that when exposed to the surface heat flow density of $30 \mathrm{~kW} / \mathrm{m}^{2}$, the time to ignition of the laminated wood chipboard $(18 \mathrm{~mm})$ was 200 seconds, that of the medium density fibreboards -83 seconds and that of the laminated wood chipboard $(29 \mathrm{~mm})-602$ seconds.

When exposed to the surface heat flow density of 50 and $70 \mathrm{~kW} / \mathrm{m}^{2}$, time to ignition is not so long any more. 


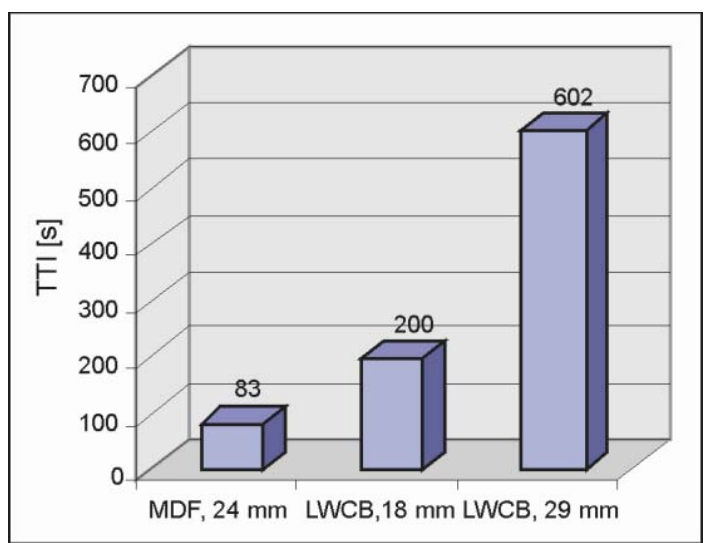

Fig. 2. Mean time to ignition (TTI) when exposed to the surface heat flow density of $30 \mathrm{~kW} / \mathrm{m}^{2}$ for different tested boards

Therefore, as the density of the surface heat flow increases, not only time to ignition gets shorter but also the difference between the three boards tested reduces. However, in all cases, $29 \mathrm{~mm}$ thick LWCB board had the longest time to ignition, whereas $24 \mathrm{~mm}$ thick MDF board had the shortest one.

It is also necessary to note that the thinnest $18 \mathrm{~mm}$ LWCB board when exposed to the surface heat flow density of 30,50 and $70 \mathrm{~kW} / \mathrm{m}^{2}$ had longer time to ignition than $24 \mathrm{~mm}$ thick MDF board (Figs. 2-4). Therefore, the longer time to ignition of a thinner wood product obtained by experiments gives occasion for thinking that a laminated surface is more resistant to higher temperature in terms of the gasification (pyrolysis) process.

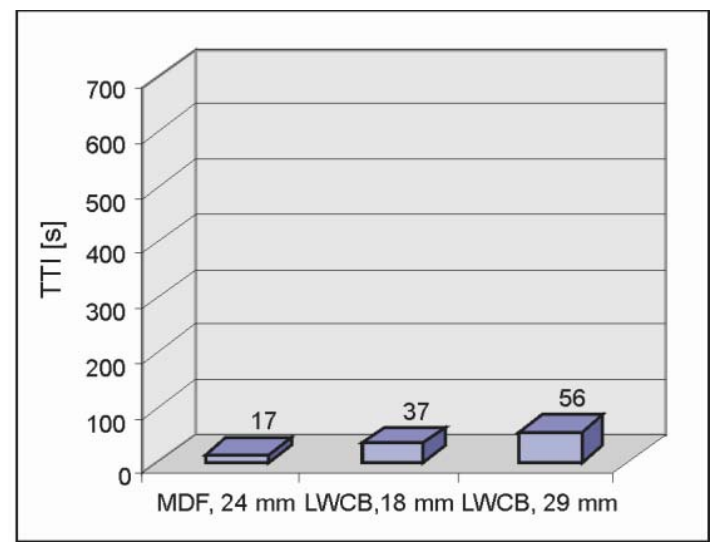

Fig. 3. Mean time to ignition (TTI) when exposed to the surface heat flow density of $50 \mathrm{~kW} / \mathrm{m}^{2}$ for different tested boards

When wood products were exposed to the surface heat flow density of $30 \mathrm{~kW} / \mathrm{m}^{2}$, the highest maximal heat release rate was that of $24 \mathrm{~mm}$ thick MDF board and the lowest $\mathrm{HRR}_{\max }$ was the one of the $29 \mathrm{~mm}$ thick LWCB board (Fig. 5).

When the same wood samples were exposed to the surface heat flow density of $50 \mathrm{~kW} / \mathrm{m}^{2}$, the values of the maximal heat release rates of $18 \mathrm{~mm}$ thick LWCB and $24 \mathrm{~mm}$ thick MDF boards increased slightly and the $\mathrm{HRR}_{\max }$ value of $29 \mathrm{~mm}$ thick LWCB board increased nearly 2.5 times (Fig. 6).

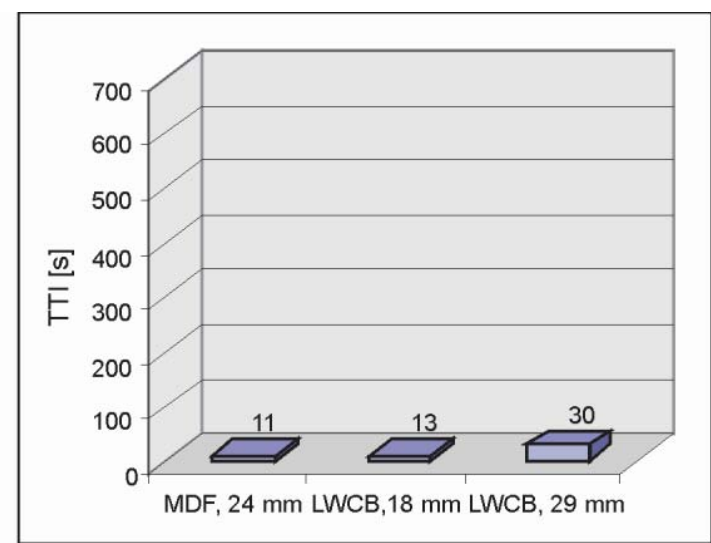

Fig. 4. Mean time to ignition (TTI) when exposed to the surface heat flow density of $70 \mathrm{~kW} / \mathrm{m}^{2}$ for different tested boards

When exposed to the surface heat flow density of $70 \mathrm{~kW} / \mathrm{m}^{2}, \mathrm{HRR}_{\max }$ values increased, however the tendency of maximal and minimal $\mathrm{HRR}_{\max }$ values remained the same as during exposure to the surface heat flow density of $30 \mathrm{~kW} / \mathrm{m}^{2}$ and $50 \mathrm{~kW} / \mathrm{m}^{2}$ (Fig. 7). It can be seen from the test curves that the $\mathrm{HRR}_{\max }$ values of all boards tested have been reached in the initial combustion phase irrespective of the type of materials, its thickness and the density of the surface heat flow. This could be explained by char formation on the sample surface which slows down the emission of volatile products and the intensity of the combustion process which in the further course of the combustion process does not allow reaching the maximal values of the heat release rate with the exception of the case when research has been conducted using the samples of the largest mass (LWCB, $29 \mathrm{~mm}$ ) where the pyrolysis process is still in progress in the initial phase of combustion.

So far, the maximal values of $\mathrm{HRR}_{\max }$ for tested $24 \mathrm{~mm}$ thick MDF boards can be explained by the highest content of the binder and paraffin (Figs. 5-7) in comparison with LWCB type boards.

However, not only the heat release rate but also time to the maximal heat release rate has a significant effect on the rate of fire spread. The high rate of heat release in the initial phase of fire severely intensifies the combustion process and conditions a fast rise in room temperature on fire (Hirschler 1999; Praniauskas 2008).

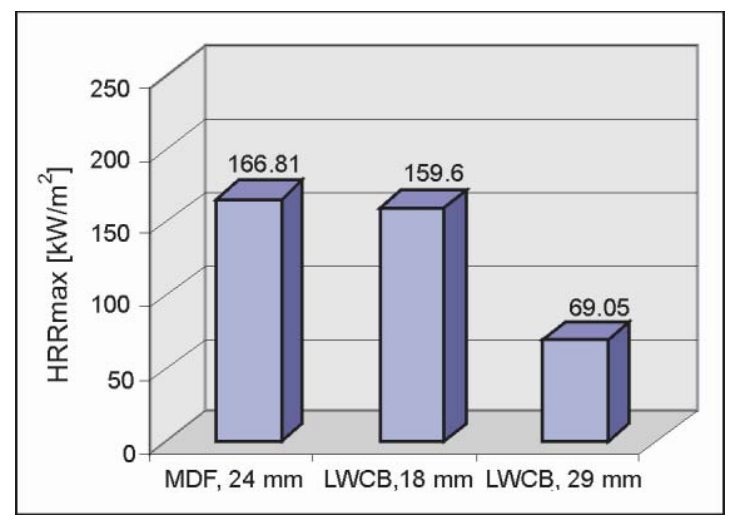

Fig. 5. The mean value of maximal heat release rate $\left(\mathrm{HRR}_{\max }\right)$ when exposed to the surface heat flow density of $30 \mathrm{~kW} / \mathrm{m}^{2}$ for different tested boards 


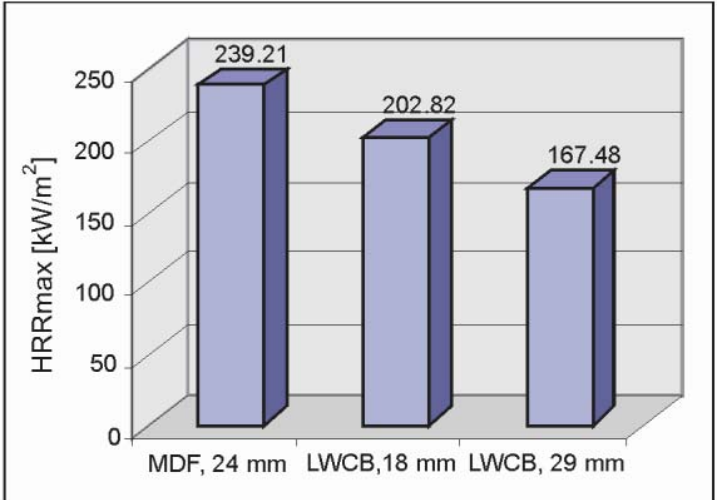

Fig. 6. The mean value of maximal heat release rate $\left(\mathrm{HRR}_{\max }\right)$ when exposed to the surface heat flow density of $50 \mathrm{~kW} / \mathrm{m}^{2}$ for different tested boards

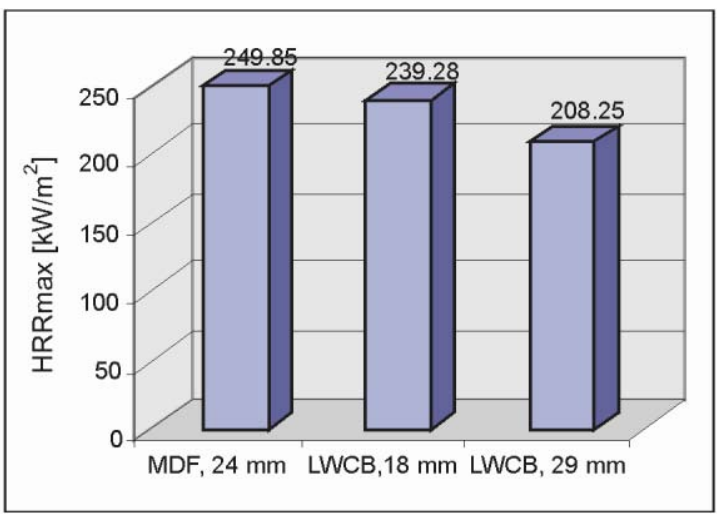

Fig. 7. The mean value of maximal heat release rate $\left(H_{R R} R_{\max }\right)$ when exposed to the surface heat flow of density $70 \mathrm{~kW} / \mathrm{m}^{2}$ for different tested boards

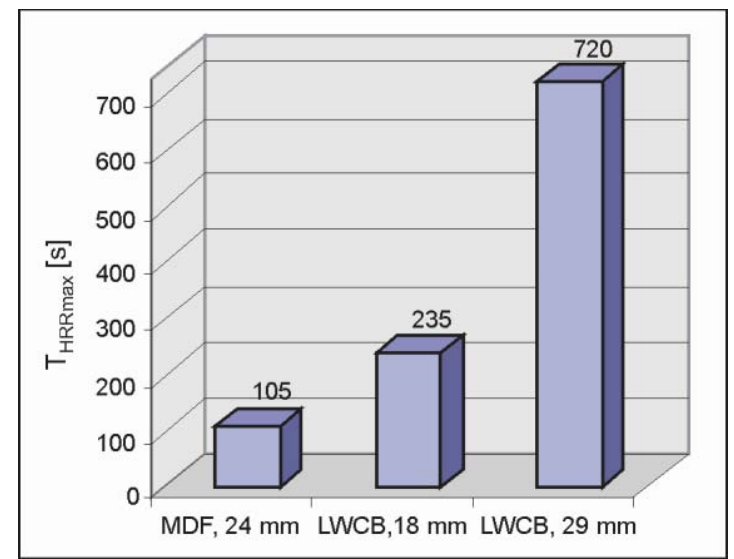

Fig. 8. Mean time to maximal heat release rate $\left(\mathrm{T}_{\mathrm{HRR} \max }\right)$ when exposed to the surface heat flow density of $30 \mathrm{~kW} / \mathrm{m}^{2}$ for different tested boards

After research had been performed, it was determined that when exposed to the surface heat flow density of $30 \mathrm{~kW} / \mathrm{m}^{2}$, the shortest time to the maximal value of the heat release rate was of $24 \mathrm{~mm}$ thick MDF board and the longest time was of $29 \mathrm{~mm}$ thick LWCB board (Fig. 8).

When exposed to the surface heat flow density of $50 \mathrm{~kW} / \mathrm{m}^{2}, \mathrm{~T}_{\mathrm{HRRmax}}$ values decrease and there is no more significant difference between them compared to exposure to the surface heat flow density of $30 \mathrm{~kW} / \mathrm{m}^{2}$.
However, the shortest $T_{\text {HRRmax }}$ was still of $24 \mathrm{~mm}$ thick MDF board and the longest $\mathrm{T}_{\text {HRRmax }}$ was of $29 \mathrm{~mm}$ thick LWCB board (Fig. 9).

When the tested boards were exposed to the surface heat flow density of $70 \mathrm{~kW} / \mathrm{m}^{2}, \mathrm{~T}_{\text {HRRmax }}$ values still decreased and the shortest time to the maximal value of the heat release rate was of $24 \mathrm{~mm}$ thick MDF board, whereas the longest time was that of $29 \mathrm{~mm}$ thick LWCB board (Fig. 10). It should also be noted that in none of the cases, $\mathrm{T}_{\text {HRRmax }}$ was the shortest for the thinnest $18 \mathrm{~mm}$ LWCB boards. This is also explained by the fact that the laminated surface is more resistant to higher temperatures, and therefore a longer period of time is required for its ignition and reaching the maximal values of the heat release rate when exposed to the heat flows of different power.

If tested materials had been exposed to the surface heat flow of 30,50 and $70 \mathrm{~kW} / \mathrm{m}^{2}$ density, the largest values of the efficient heat of combustion were of MDF board and the smallest value when exposed to the surface heat flow density of $30 \mathrm{~kW} / \mathrm{m}^{2}$ was of $29 \mathrm{~mm}$ thick LWCB. However, when exposed to the surface heat flow density of $50 \mathrm{~kW} / \mathrm{m}^{2}, 18$ and $29 \mathrm{~mm}$ thick LWCB boards reach nearly the same values. When exposed to the surface

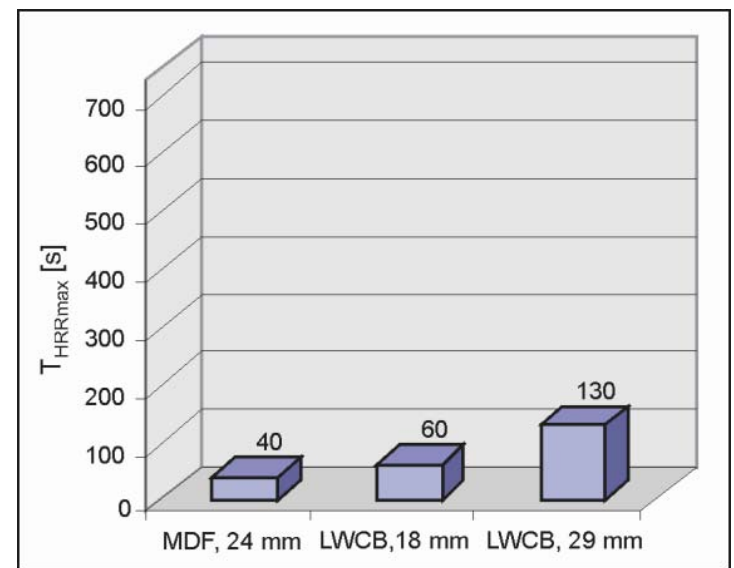

Fig. 9. Mean time to maximal heat release rate $\left(T_{H R R \max }\right)$ when exposed to the surface heat flow density of $50 \mathrm{~kW} / \mathrm{m}^{2}$ for different tested boards

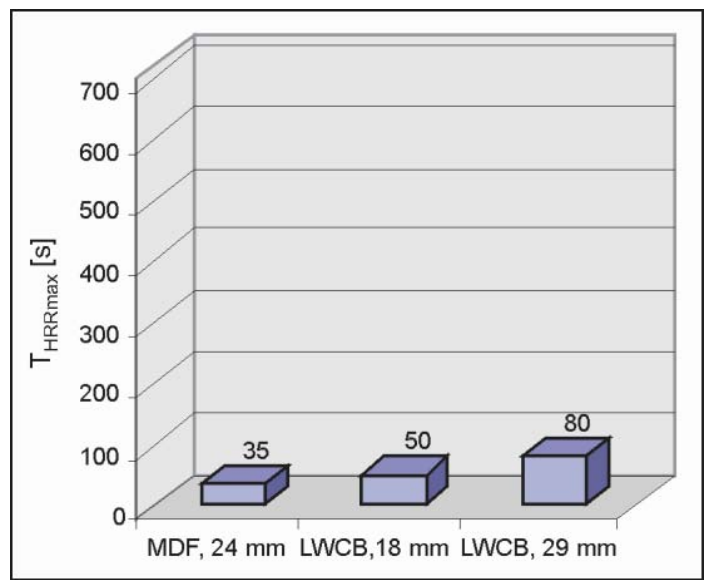

Fig. 10. Mean time to maximal heat release rate $\left(T_{H R R \max }\right)$ when exposed to the surface heat flow density of $70 \mathrm{~kW} / \mathrm{m}^{2}$ for different tested boards 


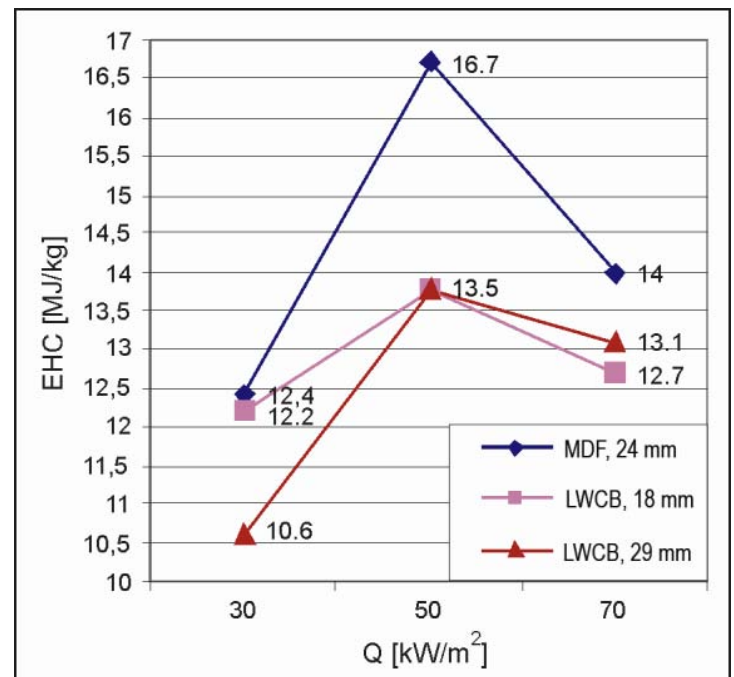

Fig. 11. Mean values of the efficient heat of combustion (EHC) when exposed to the surface heat flow of 30,50 and $70 \mathrm{~kW} / \mathrm{m}^{2}$ density for different tested boards

heat flow density of $70 \mathrm{~kW} / \mathrm{m}^{2}$, the smallest value of the EHC was characteristic to the thinnest $18 \mathrm{~mm} \mathrm{LWCB}$ board (Fig. 11).

When exposed to the surface heat flow densities of 50 and $70 \mathrm{~kW} / \mathrm{m}^{2}$, the largest values of THR were of the thickest boards and the smallest values were of the thinnest board. However, when exposed to the surface heat flow density of $30 \mathrm{~kW} / \mathrm{m}^{2}$, the largest values among the tested boards were those of the MDF board and the smallest value was that of $29 \mathrm{~mm}$ thick LWCB board (Fig. 12).

As there is more than $80 \%$ of wood in the composition of these boards, it is likely that their combustion is similar to that of wood. However, it does not mean that there are no differences between them, since additives used in the production of various wood products are to be considered. In order to reduce fire hazard of wood products, it is advisable to use inflammable or flame retardant additives (White 2000; Richardson and Batista 2001; Morkevičius and Papreckis 2004).

After research on $24 \mathrm{~mm}$ thick MDF board that was exposed to the surface heat flow density of $50 \mathrm{~kW} / \mathrm{m}^{2}$ had been performed, time to ignition was 17 seconds in our case, whereas for $12 \mathrm{~mm}$ thick MDF wood chipboards tested by Lazaros Tsantaridis and Birgit Östman exposed to the surface heat flow density of $50 \mathrm{~kW} / \mathrm{m}^{2}$, time to ignition was 39 seconds (Tsantaridis and Östman 1999).

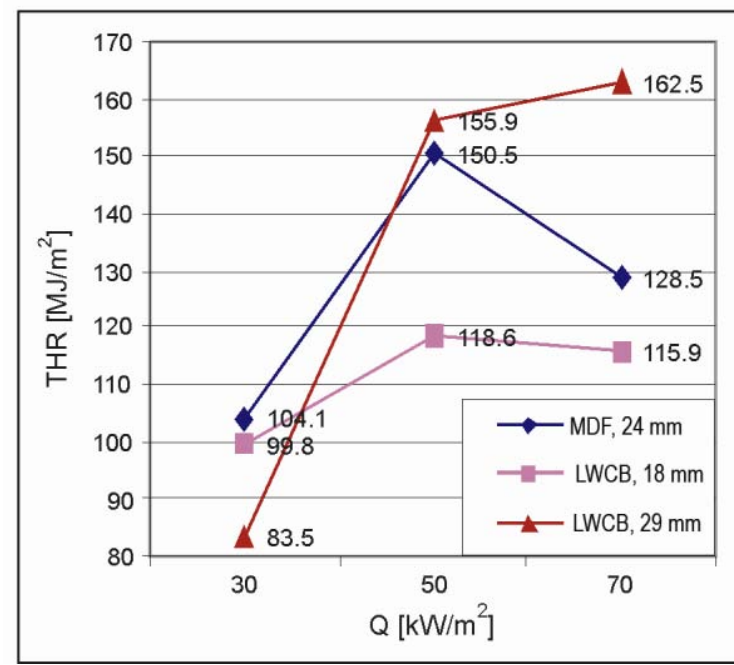

Fig. 12. Mean values of the total heat released (THR) when exposed to the surface heat flow of 30,50 and $70 \mathrm{~kW} / \mathrm{m}^{2}$ density for different tested boards

Hence, the time to ignition of a twice thicker board is more than twice shorter; therefore, flame will spread at a higher speed over our thicker board. The reason for this may be the type of additives used in production (White 2000; Richardson and Batista 2001; Morkevičius and Papreckis 2004).

Though time to ignition is of specific significance to fire spread, the rate of flame spread depends on the physical properties of the material (initial temperature, surface orientation, spreading direction, thickness, heat capacity, heat conduction, density, dimensions, homogeneity), on the chemical composition and external ambient factors (atmospheric composition, atmospheric pressure, temperature, affecting heat flow, wind speed). Attention is paid to all these factors in the computer models (Cooper and Franssen 1998; Spearpoint and Quintiere 2000; Praniauskas 2008; Półka 2008) which solve the problems related to fire spread in closed rooms in a complex manner. Therefore, the fire parameters of wood products obtained during research provide an opportunity to evaluate the effect of the properties of these products on their behaviour under real conditions only in general terms.

Having performed a regressive analysis of all tested boards, general equations (1)-(5) and their statistical parameters were obtained (Table 3 ).

Table 3. Statistic parameters of empiric equations (1)-(5)

\begin{tabular}{c|c|c|c|c|c|c|c|c}
\hline \multirow{2}{*}{$\begin{array}{c}\text { Empiric } \\
\text { equation } \\
\text { No. }\end{array}$} & \multirow{2}{*}{$\mathrm{R}$} & \multicolumn{5}{|c|}{ Calculated values of Student criterion } & \multirow{2}{*}{$\mathrm{S}_{\mathrm{e}},[\mathrm{s}]$} \\
\cline { 4 - 9 } & & & $\mathrm{X}_{1}$ & $\mathrm{X}_{2}$ & $\mathrm{X}_{3}$ & $\mathrm{X}_{4}$ & $\mathrm{X}_{5}$ & \\
\hline 1 & 0.9954 & 0.9907 & 96.943 & - & - & - & - & 17.475 \\
\hline 2 & 0.9980 & 0.9961 & 108.747 & 10.858 & - & - & - & 11.452 \\
\hline 3 & 0.9982 & 0.9965 & 62.807 & 11.533 & 3.072 & - & - & 10.934 \\
\hline 4 & 0.9985 & 0.9970 & 60.542 & 8.676 & 5.251 & 4.081 & - & 10.057 \\
\hline 5 & 0.9986 & 0.9972 & 48.631 & 2.858 & 4.684 & 4.076 & 2.100 & 9.8612 \\
\hline
\end{tabular}


Table 4. Actual and predictable TTI values

\begin{tabular}{c|c|c|c|c|c|c|c|c|c}
\hline \multirow{2}{*}{$\mathrm{Q}$} & \multicolumn{3}{|c|}{ Actual TTI value } & \multicolumn{3}{c|}{ TTI based on equation 1 } & \multicolumn{3}{c}{ TTI based on equation 5 } \\
\cline { 2 - 11 } & $\begin{array}{c}\text { MDF } \\
(24 \mathrm{~mm})\end{array}$ & $\begin{array}{c}\text { LWCB } \\
(18 \mathrm{~mm})\end{array}$ & $\begin{array}{c}\text { LWCB } \\
(29 \mathrm{~mm})\end{array}$ & $\begin{array}{c}\text { MDF } \\
(24 \mathrm{~mm})\end{array}$ & $\begin{array}{c}\text { LWCB } \\
(18 \mathrm{~mm})\end{array}$ & $\begin{array}{c}\text { LWCB } \\
(29 \mathrm{~mm})\end{array}$ & $\begin{array}{c}\text { MDF } \\
(24 \mathrm{~mm})\end{array}$ & $\begin{array}{c}\text { LWCB } \\
(18 \mathrm{~mm})\end{array}$ & $\begin{array}{c}\text { LWCB } \\
(29 \mathrm{~mm})\end{array}$ \\
\hline 30 & 83 & 200 & 602 & 70 & 182 & 603 & 83 & 199 & 601 \\
\hline 50 & 17 & 37 & 56 & 13 & 31 & 91 & 13 & 34 & 65 \\
\hline 70 & 11 & 30 & 33 & 9 & 22 & 48 & 15 & 32 & 25 \\
\hline
\end{tabular}

$$
\begin{aligned}
\mathrm{y}_{1}= & -21.355+0.867 \mathrm{x}_{1} \\
\mathrm{y}_{2}= & 68.114+0.816 \mathrm{x}_{1}-0.653 \mathrm{x}_{2} \\
\mathrm{y}_{3}= & 34.591+0.851 \mathrm{x}_{1}-0.664 \mathrm{x}_{2}+0.154 \mathrm{x}_{3} \\
\mathrm{y}_{4}= & 3.248+0.882 \mathrm{x}_{1}-0.535 \mathrm{x}_{2}+0.344 \mathrm{x}_{3}-0.516 \mathrm{x}_{4} \\
\mathrm{y}_{5}= & 7.763+0.907 \mathrm{x}_{1}-0.329 \mathrm{x}_{2}+0.551 \mathrm{x}_{3}- \\
& 0.899 \mathrm{x}_{4}-4.095 \mathrm{x}_{5}
\end{aligned}
$$

where:

$\mathrm{y}_{1-5}$ - time to ignition (TTI);

$\mathrm{x}_{1}$ - time to maximal heat release rate $\left(\mathrm{T}_{\mathrm{HRRmax}}\right)$;

$\mathrm{x}_{2}$ - total heat released (THR);

$\mathrm{x}_{3}-$ maximal heat release rate $\left(\mathrm{HRR}_{\max }\right)$;

$\mathrm{X}_{4}$ - surface heat flow density for sample $(\mathrm{Q})$ exposing;

$\mathrm{x}_{5}$ - efficient heat of combustion (EHC).

Already in the first equation, correlation coefficient $\mathrm{R}$ and determination coefficient $\mathrm{R}^{2}$ are very close to one. It is possible to draw a conclusion that the chosen model is correct and there is large dependency between the parameters (Rudzkienè, Kulvietienè 1995).

In the second, third, fourth and fifth equations, correlation and determination coefficients increased and relative error decreased as the number of criteria increased. The values of the Student criteria of all equation arguments exceeded the tabular values (Table 3 ).

Table 4 presents mean actual and predicted TTI values calculated using the first and the fifth equations. Thus, it can be seen from the obtained results that the values of TTI criteria may be quickly and accurately enough predicted based on the first equation which is of a theoretical character because the dimensions of the function and argument are identical and expressed in seconds [s]. However, more accurate results are obtained when the fifth equation is used for prediction.

\section{Conclusions}

1. It has been determined that in case of the same density and a fairly close composition of wood chipboards, mean time to their ignition decreases as surface heat flow increases. The analogous tendency is also obtained based on the prediction equations.

2. In case of laminated boards, apart from the above mentioned consistent pattern, the mean time to ignition of thicker boards increases as their thickness increases.

3. A quick prediction of time to ignition with relatively small error can be done based on time to the maximal heat release rate. The character of this equation is theoretical and the before mentioned criteria are suffi- cient for such prediction to judge about the reaction-tofire of wood chipboards.

4. All main criteria $\left(\mathrm{T}_{\mathrm{HRR} \max }, \mathrm{THR}, \mathrm{HRR}_{\max }, \mathrm{Q}\right.$ and EHC) are very important and significant in predicting time to ignition (TTI) because the coefficient of multiple correlation increases and interconnection gets stronger while prediction error reduces.

\section{References}

Cooper, L. Y.; Franssen, J. M. 1998. A basis for using fire modeling with 1-D thermall analyses of barriers/partitions to simulate 2-D and 3-D barriers/partitions structural performance in real fires. Report NISTIR 6170, BFRL.

Drysdale, D. 1998. An introduction to fire dynamics. Second edition. John wiley\&sons.

Gardner, W. D.; Thomson, C. R. 1991. Ignitability and heatrelease properties of forest products, Fire and Materials 15(1): 3-9. doi:10.1002/fam.810150103

Harada, T. 2001. Time to ignition, heat release rate and fire endurance time of wood in cone calorimeter test, Fire and Materials 25(4): 161-167. doi:10.1002/fam.766

Hirschler, M. 1999. Use of heat release rate to predict whether individual furnishings would cause self propagating fires, Fire Safety Journal 32(3): 273-296. doi:10.1016/S0379-7112(98)00037-X

International Standart ISO 5660-1. Reaction-to-fire tests - Heat release, smoke production and mass loss rate - Part 1: Heat release rate (Cone calorimeter method). 2002.

Jaskółowski, W. 2001. Szybkość zwęglania i generacji ciepła podczas spalania drewna zabezpieczonego przeciwogniowo [Rate of heat generation and formation of char on the samples surface during burning wood which is protected from fire]. Poznań.

Kim, A. 1994. Fire Properties of Room Lining Materials Measured by the Cone Calorimeter, OSU, IMO, and FullScale Room/Corner Test, in International Symposium on Fire and Flammability of Furnishings and Contents of Buildings, Miami, FL, USA, 1233: 186-200. doi:10.1520/STP12957S

Kleinbaum, D. G.; Kupper, L. L.; Muller, K. E.; Niram, A. 1998. Statistical analysis. Brooks/Cole Publishing Company.

Konecki, M.; Półka, M. 2009. Simple fire model for comparative studies of critical conditions during combustion of chosen polymer materials, Journal of Civil Engineering and Management 15(3): 247-257. doi:10.3846/1392-3730.2009.15.247-257

Mačiulaitis, R.; Lukošius, K. 2001. Aukštų temperatūrų pasiskirstymo statybinèse konstrukcijose skaičiavimo būdai ir jų taikymo analizè ịvertinant atitvarų atsparumą ugniai [Calculation methods of high temperature distribution within structural components and application of these me- 
thods to fire resistance assessment], Statyba [Civil Engineering] 7(5): 391-396.

Morkevičius, A.; Papreckis, B. 2004. Mediena ir jos gaminiai [Wood and wood products]. Vilnius: Senoja.

Nyderis, A.; Mačiulaitis, R. 1999. Putų polistirenu apšiltintų fasado fragmentu gaisriniai bandymai [Fire testing of the building facade insulated with foam polystyrene], Statyba [Civil Engineering] 5(5): 340-346.

Parker, W. J. 1982. Development of a heat release rate calorimeter of NBS, Ignition, heat release and noncombustibility of materials, ASTM STP 502: 135-151.

Półka, M. 2008. The influence of flame retardant additives on fire properties of epoxy materials, Journal of Civil Engineering and Management 14(1): 45-48. doi:10.3846/1392-3730.2008.14.45-48

Praniauskas, V. 2008. Skirtingų medienos gaminių įtaka gaisro plètrai [Influence of different wood products on the fire development], in Statyba, 11-osios Lietuvos jaunuju mokslininku konferencijos „Mokslas - Lietuvos ateitis“" (2008 04 02-04) straipsniu rinkinys, Vilnius: Technika, 84-90.

Richardson, L. R.; Batista, M. 2001. Fire resistance of timber decking for heavy timber construction, Fire and Materials 25(1): 21-29. doi:10.1002/1099-1018(200101/02)25:1< 21::AID-FAM754>3.0.CO;2-E
Rudzkienè, V.; Kulvietienè, R. 1995. Kompiuterinè duomenu analize [Computer analysis of the data]. Vilnius: Technika.

Spearpoint, M. J.; Quintiere, J. G. 2000. Predicting the burning of wood using an integral model, Combustion and Flame 123(3): 308-325. doi:10.1016/S0010-2180(00)00162-0

Tran, H. C. 1988. Rates of heat and smoke release of wood in an ohio state university calorimeter, Fire and Materials 12(4): 143-151. doi:10.1002/fam.810120402

Tsantaridis, L.; Östman, B. 1999. Mass Loss, Heat and Smoke Release for the SBI RR Products, in Fire Science \& Engineering Conference, Edinburgh Conference Center Scotland $29^{\text {Th }}$ June $-1^{\text {St }}$ July 1999, Scotland, 1409-1414.

White, R. H. 2000. Charring rate of composite timber products, in Proceedings of Wood \& Fire Safety 2000, Technical Univiversity of Zvolen, 353-363.

Władyka-Przybylak, M. 1997. Badanie skuteczności ogniochronnej powtok pęczniejacych do drewna $w$ zależności od zastosowanych mody-fikatorów [Study the effectiveness of fire-retardant coatings for wood swell, depending on the used modifiers]: Doktorska wykonana w Instytucie Włókien Naturalnych. Poznań.

Боровиков, В. П. 1998. Популярное введение в программу STATISTIKA [Borovikov, V. P. A popular introduction to the program STATISTIKA]. Москва: КомпьютерПресc.

\section{SKIRTINGAIS PAVIRŠINIO ŠILUMOS SRAUTO TANKIAIS VEIKIAMŲ MEDIENOS GAMINIŲ GAISRINIO PAVOJINGUMO TYRIMAI}

\section{R. Mačiulaitis, V. Praniauskas}

Santrauka

Straipsnyje nagrinejjami trys skirtingi medienos gaminiai, su kuriais atlikti tyrimai veikiant $30 \mathrm{~kW} / \mathrm{m}^{2}, 50 \mathrm{~kW} / \mathrm{m}^{2}$ bei $70 \mathrm{~kW} / \mathrm{m}^{2}$ paviršiniais šilumos srautais taikant ISO 5660-1 „Reaction-to-fire tests - Heat release, smoke production and mass loss rate - Part 1: Heat release rate (Cone calorimeter method)" bandymo metodą. Tyrimai atlikti su $18 \mathrm{~mm}$ ir $29 \mathrm{~mm}$ storio laminuotomis medžio drožlių plokštėmis bei $24 \mathrm{~mm}$ storio vidutinio tankio plaušo plokšte. Darbe apžvelgiamos medienos gaminių gaisrinès savybès. Aptariama bandymo metodika ir tirtų medienos gaminių procentinè sudètis. Nustatytas vidutinis laikas iki jų užsidegimo. Ištirti vidutiniai maksimalios šilumos išsiskyrimo greičio ir laiko iki ju pasiekimo dydžiai, taip pat išmatuota visa išskirta šiluma ir efektyvi degimo šiluma. Atlikta statistinè analizè, gautos empirinès lygtys, koreliacijos bei determinacijos koeficientai, standartinès paklaidos bei Stjudento kriterijai. Apibendrinami tyrimo rezultatai. Darbo pabaigoje suformuluojamos išvados.

Reikšminiai žodžiai: laikas iki užsidegimo, laikas per kurị pasiektas maksimalus šilumos išsiskyrimo greitis, maksimalus šilumos išsiskyrimo greitis, visa išskirta šiluma, medienos gaminiai, gaisrinès savybès.

Romualdas MAČIULAITIS. Prof., Dr Habil of Technological Sciences at the Department of Building Materials, Vilnius Gediminas Technical University (VGTU). Research interests: development of building materials and analysis of their characteristics.

Vladas PRANIAUSKAS. A PhD student at the Department of Building Materials, Vilnius Gediminas Technical University (VGTU). Research interests: research on fire resistance to wall constructions. 